\title{
Dominantly Inherited Hypertrophic Neuropathy
}

\author{
S. K. MONGIA, Q. GHANEM, D. PRESTON, A. J. LEWIS, AND E. A. ATACK
}

SUMMARY: Clinical, electrophysiological, and histopathological studies of some members of a family with dominantly inherited hypertrophic neuropathy are presented. Twenty-five members were studied. Seventeen were abnormal on clinical examination. Their ages varied from $2 \frac{1}{2}$ to 78 years. Age at onset in 14 of the 17 varied between $2 \frac{1}{2}$ and 56 years. Pes cavils and palpable nerve thickening were present in more than half of the affected individuals. All patients had areflexia. Fifteen of the 17 had distal motor weakness as well as mild to moderate sensory impairment. Motor weakness affecting the proximal hip and

RÉSUMÉ: Nous présentons les aspects cliniques, électrophysiologiques et histopathologiques des divers membres d'une famille avec neuropathie hypertrophique à hérédité dominante. Des 25 membres de cette famille examinés, 17 semblaient atteints. Les âges variaient de $2 \frac{1}{2}$ à 78 ans. L'âge de début déterminé chez 14 patients variait également de $2 \frac{1}{2}$ à 56 ans. Un pes cavus et une hypertrophie palpable du nerf se retrouvaient chez plus de la moitie des individus atteints. Tous étaient aréflexiques. Des 17 patients, 15 présentaient une faiblesse motrice disrale ainsi qu'une atteinte sensitive modérée. De plas 13 patients avaient aussi une faiblesse motrice proximale à shoulder girdle muscles was seen in 13 patients. Four patients gave a history of trigeminal neuralgia. Motor nerve conduction velocities were markedly impaired in all the clinically affected members. These studies were normal in the 8 unaffected members. Motor conduction velocities of the proximal segment of the ulnar nerve were slower compared to the distal segment in almost all the affected members. There was no significant correlation between the degree of clinical disability and the extent of impairment in the motor nerve conduction velocities. Sural nerve biopsies were studied. These observations are discussed.

la hanche et aux épaules. 4 patients avaient déjà souffert de névralgie du trijumeau. La vitesse de conduction nerveuse dans les nerfs moteurs était nettement diminuée chez tous les sujets atteints, alors qu'elle se situait dans les limites normales chez les sujets jugés normaux cliniquement. La vitesse de conduction motrice du segment proximal du nerf cubital était nettement plus lente que celle du segment distal, chez presque tous les sujets atteints. Cependant il n'existait aucune corrélation entre le degré d'atteinte clinique et celui du ralentissement de la conduction dans les nerfs moteurs. Des biopsies surales furent également faites.
From the Division of Neurology, Faculty of Medicine, University of Ottawa and The Ottawa Civic Hospital.

Presented at the Canadian Congress of Neurological Sciences, London, Ontario, June 1975.

Reprint requests to: Dr. E. A. Atack. Ottawa Civic Hospital, 1053 Carling Avenue, Ottawa, Ontario, KIY 4E9, Canada.
Charcot and Marie (1886) and Tooth (1886) first described an hereditary neuropathy, now called after their names, Charcot-MarieTooth disease (CMT disease). A similar disorder was described by Dejerine and Sottas (1893). Some of the other hereditary neuropathies are Refsum's disease (Refsum, 1946) hereditary sensory radicular neuropathy (Denny-Brown, 1951), Roussy-Levy syndrome (Roussy and Levy, 1926), Roussy-Cornil type of late onset (Roussy and Cornil, 1919), neuropathy of Friedreich's ataxia (McLeod, 1971), amyloid neuropathy (Bradley, 1974a) neuropathies of Bassen-Kornzweig disease (Farquhar and Ways, 1966), Tangier's disease (Kocen, Lloyd and Lascelles, 1967), porphyria (Cavanagh and Mellick, 1965) and leukodystrophies (Bradley, 1974b). Metabolic abnormalities have been recognized in some of these and it is possible that a metabolic defect exists in the others. Hypertrophy of the peripheral nerves, thought to be characteristic of Dejerine-Sottas neuropathy (also called hypertrophic interstitial neuropathy), is seen in many chronic neuropathies and signifies recurrent demyelination and remyelination of the nerves (Thomas and Lascelles, 1967; Pleasure and Towfighi, 1972). It is seen in Dejerine-Sottas neuropathy, CMT disease, Refsum's disease, amyloid neuropathy (Dyck and Lambert, 1968 a and b), diabetic neuropathy (Thomas and Lascelles, 1967), relapsing neuropathy (Austin, 1958), multifocal enlargement of peripheral nerves (Adams, Asbury and Michelson, 1965). The neuropathy of acromegaly (Stewart, 1966), neurofibromatosis (Bielschowski, 1922; Bailey and Herman, 1938), and amputation neuromas (Krucke, 1949) are other examples. Dejerine-Sottas 
TABLE 1

Age and Sex Distribution

\begin{tabular}{|c|c|c|c|c|c|}
\hline Age Group & No. & \multicolumn{2}{|c|}{ Males } & \multicolumn{2}{|c|}{ Females } \\
\hline & & \multicolumn{2}{|c|}{ Clinca1ly } & \multicolumn{2}{|c|}{ Clinically } \\
\hline & & & & & \\
\hline$<10$ years & 3 & 1 & & & 2 \\
\hline $11-20$ years & 10 & 2 & 5 & 2 & 1 \\
\hline $21-30$ years & 4 & 1 & & 1 & 2 \\
\hline $31-40$ years & 4 & & 2 & & 2 \\
\hline $41-50$ years & 3 & 1 & 1 & & \\
\hline$>50$ years & 1 & & 1 & & \\
\hline TOTAL & 25 & 5 & 9 & 3 & 8 \\
\hline
\end{tabular}

Table 2

Grading of Neurological Deficit

\begin{tabular}{|c|c|c|}
\hline Grade & \multicolumn{1}{|c|}{ Description } & No. of Patients \\
\hline I & $\begin{array}{l}\text { Areflexia with no motor or } \\
\text { sensory impairment } \\
\text { Mild weakness (4/5) with } \\
\text { III }\end{array}$ & $\begin{array}{l}\text { mild sensory impairment } \\
\text { plus areflexia } \\
\text { Moderate weakness (2-3/5) } \\
\text { with moderate sensory impair- } \\
\text { ment plus areflexia } \\
\text { Marked weakness (0-1/5) with } \\
\text { moderate sensory impairment } \\
\text { plus areflexia }\end{array}$ \\
\hline
\end{tabular}

neuropathy and CMT disease may be inherited as dominant, recessive or sex-linked traits (Bell, 1935; Austin, 1956; Thomas and Lascelles, 1967; Dyck and Lambert, 1968a). It is suggested these disorders might be better classified as dominantly or re- cessively inherited hypertrophic neuropathies rather than by eponyms.

This communication deals with the prospective study of a family with dominantly inherited hypertrophic neuropathy (Fig. 1). Detailed clinical, electrophysiological and histopathological studies are reported.

\section{METHOD OF STUDY}

This family has thirty-nine members over four generations. Twentyfive of these members were examined by one or more of us. Information was obtained about other members, but the data is restricted to those who were examined.

Of these 25 members, 17 were found to be abnormal (Table 1). These patients were divided into four groups, depending upon the severity of their clinical deficits (Table 2).

Motor nerve conduction velocities of the distal (elbow to wrist) and proximal (axilla to elbow) segments of the ulnar nerve and the knee to ankle segment of the lateral popliteal nerve were studied by conventional methods (Lambert, 1956). These studies were performed in 13 of the 17 abnormal and 6 of the 8 normal individuals (Table 3 ). Their ages varied from 11 to 50 years. Motor nerve conduction velocities of $45 \mathrm{~m} / \mathrm{sec}$ or over for the lateral popliteal nerve were considered normal. Nerve conduction velocities in the affected members were classified into grades I-III as shown in Table 4. A decrease of $10 \mathrm{~m} / \mathrm{sec}$ of conduction velocity separated one grade from the other. The grading of nerve conduction velocities and the clinical deficits was designed arbitrarily.

Sural nerve biopsy was available from patients $\mathrm{B} 1, \mathrm{~B} 4, \mathrm{C} 10, \mathrm{C} 11$, $\mathrm{C} 12$, and $\mathrm{C} 13$ as shown in Figure 1. Gastrocnemius muscle biopsies were available from patients $B 1$ and C13. All specimens were picked up immediately and prepared for teasing (of nerves), frozen section, paraffin section and electronmicroscopy. Standard techniques used for nerve and muscle included qualitative histochemistry and enzyme histochemistry.

All patients were subjected to the following hematological and biochemical studies: total and differential blood cell counts; hemoglobin; erythrocytic sedimentation rate; serum levels of sodium, potassium, 

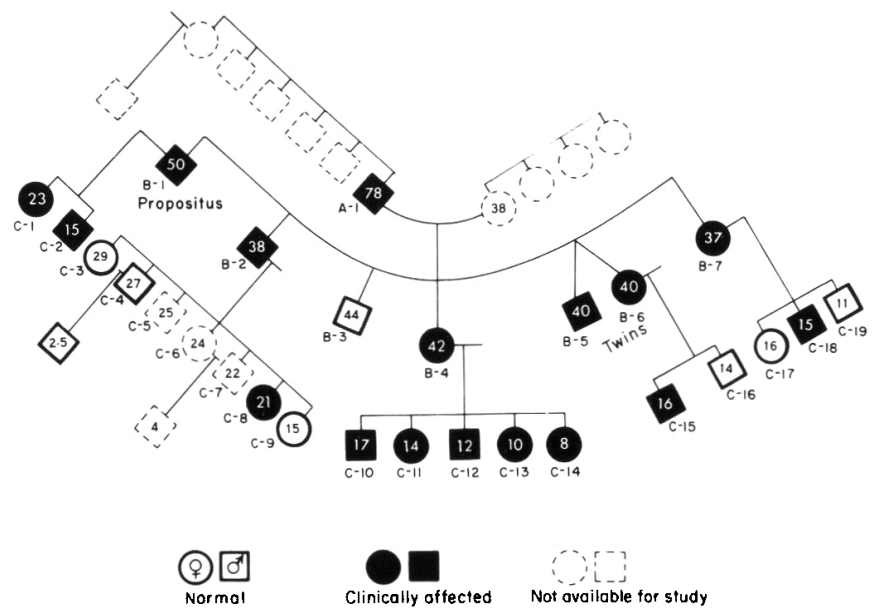

Figure I-Family pedigree showing both female and male individuals that were normal. clinically affected, or not available for study.
AGE OF ONSET

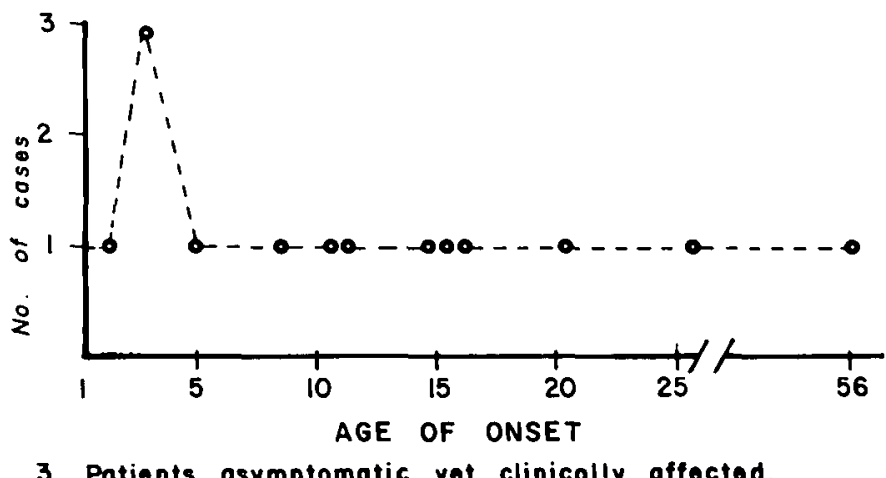

Figure 2 -The dots indicate the number of cases as they started their symptoms at a particular age in years. Three patients were asymptomatic but clinically affected and are not included in this figure. chloride, calcium, phosphorus, alkaline phosphatase, SGOT SGPT, fasting and post-prandial blood sugar. Serum electrophoresis for proteins and lipoproteins and serological tests for syphilis were performed. Blood levels of arsenic, lead, mercury, and phytanic acid were assessed and X-rays of spine were taken in some of the patients.

\section{OBSERVATIONS}

Of the 17 abnormal members, 9 were males (Table 1). The disorder was inherited as an autosomal dominant trait (Fig. 1). No sex predominance was seen.

Two members of the family, B- 5 and B-6 in Fig. 1, a male and a female, were twins. Both of them had moderate peripheral neuropathy. Motor nerve conduction velocities were slow in one of them (B-6) and she had transmitted the disease to one of her two children. This was confirmed by clinical and nerve conduction studies.

At the time of the examination, their ages varied from $2 \frac{1}{2}$ to 78 years (Table 1). Twelve of the 14 patients had the onset of illness some time before 20 years of age. Of these, five began at $2 \frac{1}{2}$ to 5 years of age. There were two patients who had their first symptoms at 25 and 56 years of age (Fig. 2).

Examination of intellectual functions and cranial nerves revealed no abnormalities. None of the patients showed tremor, pupillary abnormalities, nystagmus, cerebellar or long tract signs. Pes cavus and palpable nerve thickening were found in more than half of the patients.

Mild to marked motor and moderate sensory deficits were seen in 15 of the 17 patients. The other two patients had no weakness, although they were areflexic and showed abnormal nerve conduction velocities. Absent deep tendon reflexes was a

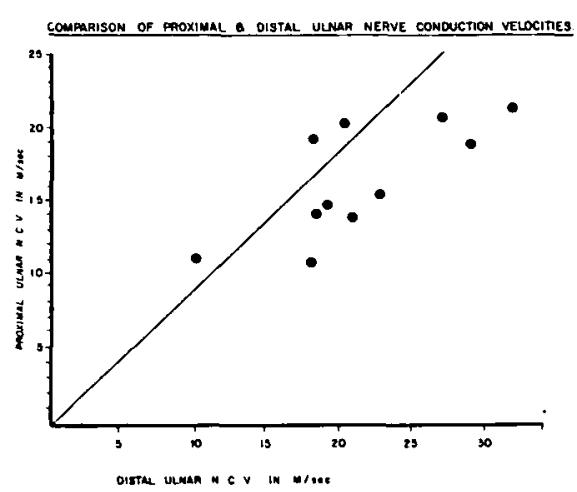

Figure 3 - Comparison of the proximal and distal ulnar nerve conduction velocities (N.C.V.) in meters per second $(\mathrm{M} / \mathrm{sec})$ in affected individuals. The dots indicate distal nerve con: duction velocity as shown on the horizontal line and the proximal nerve conduction velocity as plotted on the vertical line in the same individual. In 9 of the 12 patients, the motor nerve conduction velocity of the proximal segment was lower compared to that of the distal segment. feature of all the patients. Distal weakness of the lower extremities was seen in 15 patients. Thirteen of these 15 had weakness of the distal muscles of the upper extremities.

Thirteen of the 15 patients had significant proximal weakness, mostly in the lower limbs. The pro-

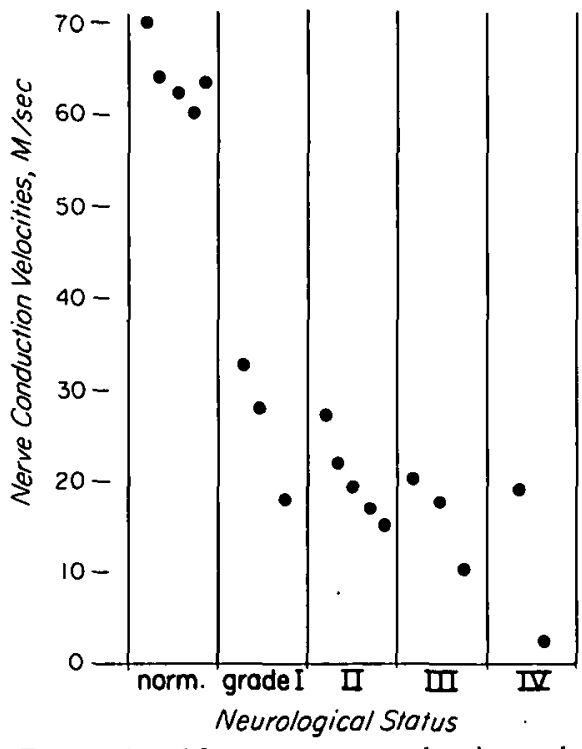

Figure 4 - Motor nerve conduction velocities of ulnar nerve. as indicated by the black dots, are correlated to the neurological status in normal (norm) and affected individuals. The neurological status of affected members was graded I-IV (please see the text). There is some tendency for the nerve conduction velocities to show a lower value in more severely affected members. 
ximal weakness affected the lower extremities in six, the lower and the upper extremities in another six, and only the upper extremities in one (Fig. 3). The proximal weakness involved predominantly the hip flexors and the shoulder abductors. Fasciculations were seen in the proximal arm muscles in one patient while, subjectively, the fasciculations were felt in the proximal muscles by four other patients.

Sensory examination showed mild to moderate impairment of distal vibration and position sense of the lower and upper extremities. Pain and temperature modalities were not affected.

Four patients, including the propositus, had a history of trigeminal neuralgia. Two of these had nerve blocks to relieve their pain. The other two had medical treatment for variable periods.

Motor nerve conduction studies were performed in 19 members of the family. Clinically, 13 of the 19 were affected, while six had no neurological deficit (Table 3). The 13 affected members had abnormal motor nerve conduction velocities, while the six healthy members had normal nerve conduction velocities. In the affected group, areflexia was the only abnormality in two.

Motor conduction velocities of the distal and proximal segments of the ulnar nerve were compared in 11 patients. In eight of the 11 the proximal segment showed lower conduction velocity compared to the distal segment.

An attempt was made to correlate the nerve conduction velocities with the severity of the neurological deficit (Fig. 5). Only motor nerve conduction velocities of the ulnar nerve were used for this correlation. The normal members had normal nerve conduction velocities. In the affected members the motor conduction velocities were reduced in all grades of neurological deficit and the reduction was approximately proportional to the grade of the disease.

None of the hematological or biochemical studies was abnormal.

Sural nerve biopsies showed no changes in epineurium, perineurium or vessels. The most severely af-

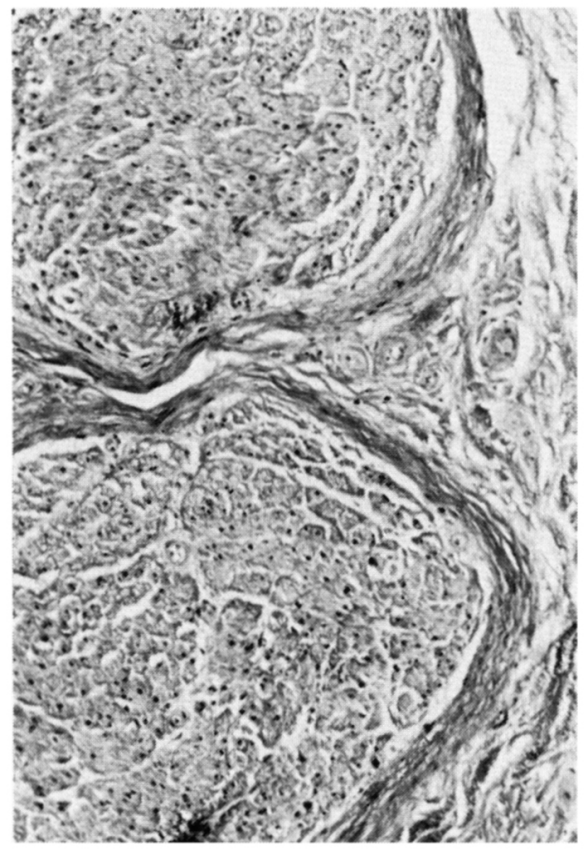

Figure 5 - Transverse section of two fasciculae, showing clumps of thickened endoneurium but normal perineurium (Masson's trichrome, $x$ 400)

fected nerves (B1, B4, and C11) showed almost complete loss of myelin with moderate reduction of large axons. The endoneurial content of collagen (trichrome stain) and basement membrane material (reticulin stain) was markedly increased, and there was a moderate increase in Schwann cell nuclei. On transverse section the increased endoneurial tissue formed small clusters (Fig. 6), but onion bulb formation was not clearly visible under light microscopy. There was no accumulation of myelin breakdown products (ORO-positive or PASpositive material). In one case (B4) there were apparently "empty" spaces in the endoneurium, which contained finely granular mucopolysaccharide (Alcian Blue).

Teased preparation (Fig. 7) showed a marked increase in longitudinally orientated collagen fibers and bundles, and very few continuous myelin sheaths. Most of these were thin and palely stained compared with control material. Some fibers showed multisegmental demyelination with or without ellipsoidal accumulations of osmiophilic material. Occasionally, segmental or paranodal demyelination could be recognized.

Electronmicroscopy confirmed severe reduction in numbers of myelin sheaths. Most of the remaining sheaths were thin, and showed morphological abnormalities, including vesiculation at the minor dense line, distorted and separated lamellae especially in the inner part of the sheath, and areas of irregular thickening. Large axons, presumably demyelinated, appeared normal. Small fibers were plentiful, and appeared morphologically normal. A few empty Schwann cell profiles, with occasionally collagen pockets, were present. Onion bodies with 3 to 6 concentric lamellae of Schwann cell cytoplasm were present (Fig. 7), the lamellae being interspersed with and surrounded by large numbers of collagen fibers. Redundant basement membrane material was sometimes seen.

The other three biopsies showed similar changes, but in lesser degree. In $\mathrm{C} 12$ and $\mathrm{C} 13$, there was moderate endoneurial thickening, but few well-formed onion bulbs. Teased preparations showed more myelinated axons, with areas of consecutive segmental demyelination. In C10, changes were minimal except for some segmental demyelination in the teased preparations. No Renaut bodes were seen in any biopsy.

Both muscle biopsies showed denervation atrophy. In B1, there was advanced muscle fiber loss with fibro-fatty replacement; the remaining small muscle fibers (less than $15 \mu$ ) could not be typed, since they all showed well-marked oxidative activity with variable levels of ATPase and phosophorylase. In C13, there was less advanced atrophy selectively involving type I fibers, most of which were less than $30 \mu$ in diameter, but no stromal changes. There was no type grouping, hypertrophy, or other evidence of reinnervation.

\section{DISCUSSION}

Hypertrophic neuropathies of the type known as CMT disease and Dejerine-Sottas disease have been classified into five types by Bradley 

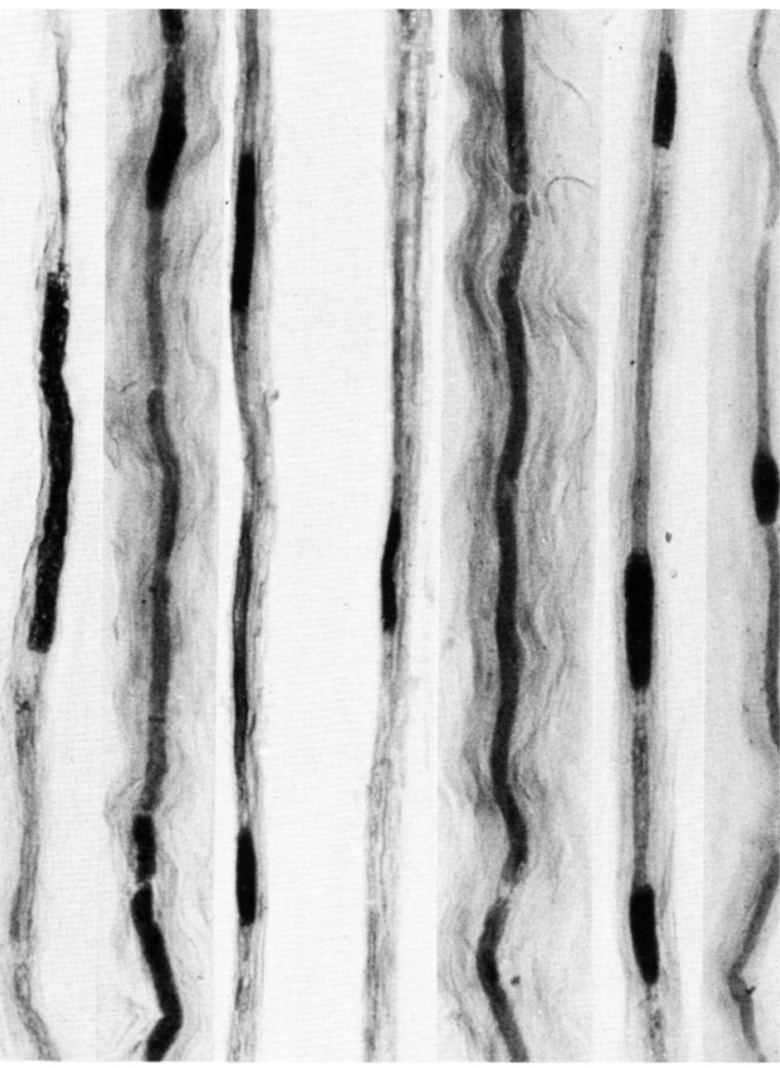

Figure 6-Representative teased nerve fibers, showing preserved original myelin in often incomplete segments, ovoids of abnormally formed myelin, extensive thin remyelination, and endoneurial fibrosis (onion bulbs). (Osmium tetroxide, x 900).

(1974a). Mode of inheritance, age of onset, and progression of the disease were some of the main differentiating features. In our cases, the age of onset varied from $2 \frac{1}{2}$ to 56 years. Progression of the disease was also variable. For example, the propositus became aware of his disability at 15-20 years of age. He was confined to a wheelchair several years before he died, of an unrelated problem, at the age of 50 . He had five affected siblings. Their symptoms started at ages 5-15 years and were only moderately disabling in the next 20-30 years. A similar variability in the progression was seen in other affected members. Apparently, age of onset and speed of progression are not reliable classifying features.

Nystagmus, tremor, miosis, and cerebellar or long tract signs were not seen in any of our patients. Nystagmus and miosis described in Dejerine-Sottas neuropathy is not a consistent feature. None of the five patients of Dyck and Lambert (1968 a) had either. These signs, therefore, are not helpful in separating CMT disease from Dejerine-Sottas neuropathy.

Sensory loss, although described as most severe in Dejerine-Sottas disease, is predominant for the modalities of light touch, vibration and position sense (Dyck and Lambert, 1968a). Similar predominance for these modalities is seen in CMT disease. Severe sensory impairment for pain and other sensations, including trophic disturbances, have been described in CMT disease by England and Denny-Brown (1952).

Hypertrophy of the peripheral nerves is not exclusive to DejerineSottas disease. This finding has been described in many other neuropathies.

Nerve conduction velocities are generally low in the hereditary neuropathies. These studies have been utilized in the affected mem- bers, and in detecting the carriers of the gene, who have not yet manifested the disease (Lambert et al., 1958; Dyck et al., 1963).

In the present series, the impairment of deep tendon reflexes, with or without other clinical signs, was as sensitive an indicator of the disease as the abnormalities on nerve conduction studies. Those members with impairment of deep tendon reflexes also showed abnormal motor nerve conduction velocities. The velocities were normal in those with normal deep tendon reflexes.

Pathological examination is of little assistance in the classification of familial or sporadic hypertrophic neuropathies, all of which show similar changes exemplified by the present cases (Thomas and Lascelles, 1967; Dyck and Lambert, 1968b). These include loss of myelin by segmental demyelination frequently accompanied by remyelination, variable loss of large axons but 
TABLE 3

Nerve Conduction Velocities: Clinically Normal and Affected Members.

\begin{tabular}{|c|c|c|c|c|}
\hline $\begin{array}{l}\text { Clinical Status } \\
\text { of Individuals }\end{array}$ & No. & $\begin{array}{l}\text { Motor Nerve } \\
\text { Not Done }\end{array}$ & $\begin{array}{c}\text { Conduction } \\
\text { Normal }\end{array}$ & $\begin{array}{l}\text { Velocities } \\
\int \text { Abnormal }\end{array}$ \\
\hline $\begin{array}{l}\text { Clinically } \\
\text { Normal Members }\end{array}$ & 8 & 2 & 6 & 0 \\
\hline $\begin{array}{l}\text { Clinically } \\
\text { Affected } \\
\text { Members }\end{array}$ & 17 & 4 & 0 & 13 \\
\hline
\end{tabular}

TABLE 4

Nerve Conduction Velocities: Clinically Affected Members

\begin{tabular}{|c|c|c|c|c|c|}
\hline \multirow[b]{2}{*}{ Nerve } & \multirow[b]{2}{*}{$\begin{array}{c}\text { No. of } \\
\text { Patients }\end{array}$} & \multicolumn{3}{|c|}{ Nerve Conduction Velocities } & \multirow[b]{2}{*}{$\begin{array}{l}\text { Grade III } \\
25 \mathrm{~m} / \mathrm{sec}\end{array}$} \\
\hline & & $\begin{array}{c}\text { Norma1 } \\
44 \mathrm{~m} / \mathrm{sec} \text {. }\end{array}$ & $\begin{array}{c}\text { Grade I } \\
35-44 \mathrm{~m} / \mathrm{sec} .\end{array}$ & $\begin{array}{c}\text { Grade II } \\
25-34 \mathrm{~m} / \mathrm{sec} .\end{array}$ & \\
\hline $\begin{array}{l}\text { Distal } \\
\text { Ulnar }\end{array}$ & 13 & 0 & 0 & 3 & 10 \\
\hline $\begin{array}{l}\text { Proximal } \\
\text { Ulnar }\end{array}$ & 12 & 0 & 0 & 0 & 12 \\
\hline Nerve & $\begin{array}{l}\text { No. of } \\
\text { Patients }\end{array}$ & $\begin{array}{l}\text { Normal } \\
40 \mathrm{~m} / \mathrm{sec} \text {. }\end{array}$ & $\begin{array}{c}\text { Grade I } \\
30-39 \mathrm{~m} / \mathrm{sec} .\end{array}$ & $\begin{array}{c}\text { Grade II } \\
20-29 \mathrm{~m} / \mathrm{sec} .\end{array}$ & $\begin{array}{l}\text { Grade III } \\
20 \mathrm{~m} / \mathrm{sec}\end{array}$ \\
\hline $\begin{array}{l}\text { Late'ral } \\
\text { Popliteal } \\
\text { Nerve }\end{array}$ & 9 & 0 & 0 & 0 & 9 \\
\hline
\end{tabular}

usually normal small axons, proliferation of Schwann cells with the formation of onion bulbs, marked increase in endoneurial collagen fibers, and variable accumulation of acid mucopolysaccharide in the distended ground substance. Microscopy may assist in the exclusion of somewhat similar conditions, such as Refsum's disease (Fardeau and Engel, 1969). Fabry's disease (Kocen and Thomas, 1970; Ohnishi and Dyck, 1974), or Tangier disease (Kocen, King, Thomas and Haas, 1973), in which lipid inclusions of more or less specific nature may occur in well-defined situations.

The mode of inheritance seems to be the most useful guide for differentiating these various types of hereditary neuropathy, calling them either dominantly inherited hypertrophic neuropathy or recessively inherited hypertrophic neuropathy.

Thirteen of the 17 clinically affected individuals in the present study had mild-moderate weakness of the hip and shoulder girdle muscles. This was distinct from the distal weakness in both the upper and lower extremities. For example, many of these patients showed weakness of the dorsiflexors and everters of the feet and some weakness of the hip flexors, with comparatively preserved strength of the knee flexors and extensors. The proximal weakness of both lower and upper extremities has not been described in cases of CMT or Dejerine-Sottas disease. This proximal motor involvement was pre- sumably neuropathic. Subjective and objective fasciculations in some of the patients and relatively slower motor nerve conduction velocities in the proximal compared to the distal segment of the ulnar nerve support this contention.

Four of our 17 patients complained of trigeminal neuralgic pains. Kimura (1971) found electrophysiological evidence of facial and trigeminal nerve involvement in CMT disease. Kalynanaraman et al (1974) reported a case of hereditary hypertrophic neuropathy with facial and trigeminal nerve involvement. This patient had trigeminal neuralgic pains and facial hemispasms. Electrophysiologically, the facial nerve was found to have reduced conduction time. This isolated patient was presumed to have autosomal recessive inheritance and was diagnosed as a case of Dejerine-Sottas neuropathy. They found similarities between their case and the cases described by Hellsing (1930) and later restudied by Lundberg and Westerberg (1968). The cases described by the latter authors had facial spasms, optic atrophy, Argyll-Robertson pupils, disturbed eye movements, diminished or absent deep tendon reflexes, slight to moderate peripheral weakness in the legs and electrophysiological evidence of motor peripheral neuropathy. Two of their patients were said to have trigeminal neuralgia. These workers confirmed the dominant inheritance of the syndrome and concluded that Hellsing's cases represented a unique syndrome of hereditary neuropathy. The case described by Kalyanaraman et al. (1974) was believed to have recessive inheritance, while the cases described as Hellsing's syndrome had a dominant inheritance. We agree with the suggestion that the cases described by Hellsing, Kalyanaraman et al, as well as our patients, represent hereditary hypertrophic neuropathy with cranial nerve involvement and other atypical features. Our cases had the unusual feature of proximal muscle weakness, not emphasized in the literature.

The pathogenesis of these 
hereditary neuropathies is not clear. A metabolic error has been elucidated in cases of Refsum's disease. Phytanic acid, a free fatty acid, is increased in the blood and elsewhere (Klenke and Kahlke, 1963). Dyck et al. (1970) found evidence of an abnormal metabolism of ceramide hexosides and ceramide hexoside sulphates in recessively inherited hypertrophic neuropathy (DejerineSottas neuropathy). A metabolic abnormality of genetic type is almost certainly involved in cases of dominantly inherited hypertrophic neuropathy. A dominant inheritance with high penetrance is evident from our cases (Fig. 1). This is also suggested by the fact that two of our cases, B5 and B6 in Figure 1, born as dizogotic twins, both suffered from the neuropathy.

In 1970, Dyck et al., from the study of sural nerves in dominantly inherited hypertrophic neuropathy, postulated that the synthesis or maintenance of myelin was the primary defect. In 1974, they revised their opinion. Based on biopsy study of saphenous nerves at mid-thigh and ankle levels, Dyck, Lais and Offord (1974) proposed that the peripheral neurons, motor neurons in the spinal cord, and the sensory neurons in the dorsal root ganglion were the site of the primary lesion. An unknown inborn error of metabolism in the peripheral neurons was presumed to interfere with the proper synthesis or transport of materials essential for the integrity of the nerve cells, thereby causing neuronal atrophy and, subsequently, the peripheral neural atrophy. Segmental demyelination, as seen histopathologically, was presumed to take place secondary to the axonal atrophy. Abnormalities in axonal flow supported this hypothesis described by Brimijoin, Capek and Dyck (1973). Christie (1961), as a result of his interesting electrophysiological studies, theorized that CMT disease was a degenerative disorder of anterior horn cells which failed to "pump" axoplasm to the distal parts of the peripheral nerves.

However, moderate to marked reduction of conduction velocities in the presence of relatively intact motor and sensory functions, as seen in some of our cases and stressed by earlier workers (Lambert et al., 1958; Dyck et al., 1963), would be difficult to explain on the basis of a primary neuronal degeneration. A slowly progressive disorder of myelin would seem more reasonable.

\section{REFERENCES}

ADAMS. R. D., ASBURY, A. K, and MICHELSEN, J. J. (1965). Multifocal pseudohypertrophic neuropathy. Transactions of the American Neurological Association (New York), 90, 30-32.

AUSTIN, J. H. (1956). Observations on the syndrome of hypertrophic neuritis. (The hypertrophic interstitial radiculopathies). Medicine (Baltimore), 35, 187-237.

AUSTIN, J. H. (1958). Recurrent polyneuropathies and their corticosteriod treatment. Brain, 81, 157-192.

BAILEY, P. and HERRMAN, J. D. (1938). The role of the cells of Schwann in the formation of tumours of the peripheral nerves. American Journal of Pathology, 14, 1-38.

BELL, J. (1935). Treasury of human inheritance. in: Nervous Diseases and Muscular Dystrophies; "on the peroneal type of progressive muscular atrophy," in Fisher. R. A. (Ed). Treasury of Human Inheritance; Nervous Diseases and Muscular Dystrophies. London; Cambridge University Press, 1935, vol. 4, pp. 69-139.

BIELSCHOWSKY, M. (1922). J. Psych Neurol (Lf2) 29, 182.

BRADLEY, W. G. (1974a). Disorders of peripheral nerves. London, Blackwell Scientific Publications, pp 148-215.

BRADLEY, W. G. (1974b). The neuropathies in Disorders of Voluntary Muscle, 3rd edition. Ed. Walton, J. N., pp 804, Churchill Livingstone, London.

BRIMIJOIN, S.. CAPEK, P. and DYCK, P. J. (1973). Axonal transport of dopamine-B hydroxylase by human sural nerves in vitro. Science, 180, 1295-1297.

CAVANAGH, J. B. and MELLICK, R. S. (1965). On the nature of peripheral nerve lesions associated with acute intermittent porphyria. Journal of Neurology. Neurosurgery and Psychiatry, 28, 320-327.

CHARCOT, J. M. and MARIE, P. (1886). Sur une forme particuliere datrophie musculaire progressive; souvent familial debutant par les pieds et les jambes, et atteignant plus tard les mains. Revue Medicine, (Paris), 6, 97-138.

CHRISTIE, B. G. (1961). Electrodiagnostic features of Charcot-Marie-Tooth disease. Proceedings Royal Society of Medicine. 54, 321-324.

DEJERINE, J. and SOTTAS, J. (1893). Sur la nevrite interstitielle hypertrophique et progressive de l'enfance. Comptes Rendus, des Seances ae la Societe de Biologie et de ses Filiales (Paris), 45, 63-96.

DENNY-BROWN, D. (1951). Hereditary sensory radicular neuropathy. Journal of Neurology, Neurosurgery and Psychiatry, 14, 237-252.

DYCK, P. J., LAMBERT, E. A. and MULDER, D. W. (1963). Charcot-Marie-Tooth disease: nerve conduction and clinical studies of a large kinship. Neurology (Minneapolis). 13, $1-11$.

DYCK, P. J. and LAMBERT, E. H. (1968a). Lower motor and primary sensory neurone diseases with peroneal muscular atrophy. I. Neurologic, genetic and electrophysiologic findings in hereditary polyneuropathies. Archives of Neurology (Chicago), 18, 603-618.

DYCK, P. J. and LAMBERT. E. H. (1968b). Lower motor and primary sensory neurone diseases with peroneal muscular atrophy. II. Neurologic, genetic and electrophysiological findings in various neuronal degenerations. Archives of Neurology (Chicago), 18, 619-625.

DYCK, P. J., ELLEFSON, R. D., L.AIS, A. C., SMITH, R. C., TAYLOR, W. F. and VAN DYKE, R. A. (1970). Histologic and lipid studies of sural nerves in inherited hypertrophic neuropathy: Preliminary report of a lipid abnormality in nerve and liver in Dejerine-Sottas disease. Mayo Clinic Proceedings, 45, 280-327.

DYCK, P. J., LAIS, A. C. and OFFORD, K. $P$. (1974). The nature of myelinated nerve fiber degeneration in dominantly inherited hypertrophic neuropathy. Mayo Clinic Proceedings, 49, 34-39.

ENGLAND, A. D. and DENNY-BROWN. D. (1952). Severe sensory changes and trophic disorder in peroneal muscular atrophy (Charcot-Marie-Tooth type). Archives of Neurology, 67, 1-17.

FARDEAU, M. and ENGEL, W. K. (1969). Ultrastructural studies of a peripheral nerve in Refsum's disease. Journal of Neuropathology and Experimental Neurology, 28, 278-294.

FARQUHAR, J. W. and WAYS, P. (1966). Abetalipoproteinemia in Metabolic Basis of Inherited Disease, 2nd edition. Ed. Stanbury, J. B., Wyngaarden, J. B. and Fredrickson, D. S., pp. 509-522. McGraw-Hill, New York.

HELLSING, G. (1930). Hereditarer fascialiskranipf. Acta Medica Scandinavica, 73. 526-537.

KALYANARAMAN, K., SMITH, B. H. and SCHLAGENHAUFF. R. E. (1974). Hereditary hypertrophic neuropathy with facial and trigeminal involvement. Report of a case and comments on its possible identity with Hellsing's syndrome. Archives of Neurology, 31, 15-17.

KIMURA, J. (1971). An evaluation of the facial and trigeminal nerves in polyneuropathy: Electrodiagnostic study in Charcot-Marie-Tooth disease, Guillain- 
Barre syndrome and diabetic neuropathy. Neurology, 21, 745-752.

.KLENKE, E. and KAHLKE, W. (1963). Uber das vorkommen der $3,7,11,15$ tetramethyl-hexadecansaure in den cholisterinestern and anderen lipoidfraktionen der organe bein einemkrankheitsfall unbekannter genese (verdacht auf heredopathia atactica poly-neuritiformis (Refsumsyndrome) Hoppe-Seulers Zietschrift fur Physiologische Chemie (Berlin), 333, 133-139.

KOCEN, R. S., LLOYD, J. K., LASCELLES, P. T., FASBROOKE, A. S., and WILliAMS, D. (1967). Familiallipoprotein deficiency (Tangier's disease) with neurological abnormalities. Lancet, 1 , 1341-1345.

KOCEN, R. S. and THOMAS P. K. (1970). Peripheral nerve involvement in Fabry's disease. Archives of Neurology, 22, 81-88.

KOCEN, R. S., KING, R. H. M., THOMAS, P. K. and HAAS, L. F. (1973). Nerve biopsy findings in two cases of Tangier disease. Acta Neuropathologica, 26, 317.327.

KRUCKE, W. (1949). Histopathologische unitersuchungen der Schussverlet-zungen peripheren nervensystems. Allgemeine Sietschrift fur Psychiatrie und Ihre Grenzhebiete, 124, 361-365.

LAMBERT, E. H. (1956). Electromyography and electric stimulation of peripheral nerves and muscles in: Clinical Examination in Neurology. (Philadelphia), W. B. Saunders. pp 287-317.

LAMBERT, E. H., BASTRON, J. A. and MULDER, D. W. (1958). Conduction velocity of motor fibres of peripheral nerves in peroneal muscular atrophy (CMT disease), read before the Annual Meeting of the American Academy of Neurology, Philadelphia, April 19, 1958.

LUNDBERG, P. O. and WESTERBERG, C. E. (1968). A hereditary neurological disease with facial spasm. Journal of Neurological Sciences, 8, 85-100.

McLEOD, J. G. (1971). An electrophysiological and pathological study of peripheral nerves in Friedreich's ataxia. Journal of Neurological Sciences, 12, 333-349.

OHNISHI, A. and DYCK, P. J. (1974). Loss of small peripheral sensory neurones in Fabry's disease. Archives of Neurology, 31, 120-127.
PLEASURE, D. E. and TOWfighi J. (1972). Onion bulb neuropathies. Archives of Neurology, 26, 289-301.

REFSUM, S. (1946). Heredopathia atactica polyneuritiformis: Familial syndrome not hitherto described. Acta Psychiatrice Scandinavica, Suppl, 38, 1-303.

ROUSSY, G. and CORNIL, L. (1919). Nevrite hypertrophique professive non-familial de l'aulte. Annales de Medicine. (Paris) 6. 296-305.

ROUSSY, G. and LEVY, G. (1926). Sept cas d'une maladie familiale particuliere: Trouble de lar march, pied bots et areflexie tendineuse generalisee, avec accessoirement, Legere maladresse des maines. Reveu Neurologique (Paris), 1, 427-450.

STEWART, B. M. (1966). Hypertrophic neuropathy of acromegaly: A rare neuropathy associated with acromegaly. Archives of Neurology, 14, 107-110.

THOMAS, P. K. and LASCELLES, R. C. (1967). Hypertrophic neuropathy. Quarterly Journal of Medicine, 36, 223-238.

TOOTH, H. H. (1886). The peroneal type of progressive muscular atrophy. Thesis, University of London. H. K. Lewis, London. 